\title{
Stakeholder perceptions of components of a Parkinson disease care management intervention, care coordination for health promotion and activities in Parkinson's disease (CHAPS)
}

\author{
Karen I. Connor ${ }^{1,2,3^{*}}$ (D), Hilary C. Siebens ${ }^{4}$, Brian S. Mittman ${ }^{5}$, Donna K. McNeese-Smith ${ }^{6}$, David A. Ganz ${ }^{2,7}$,
} Frances Barry ${ }^{2}$, Lisa K. Edwards', Michael G. McGowan', Eric M. Cheng ${ }^{2}$ and Barbara G. Vickrey ${ }^{8}$

\begin{abstract}
Background: A recent nurse-led proactive care management intervention, Care Coordination for Health Promotion and Activities in Parkinson Disease (CHAPS), improved care quality when compared to usual care in a randomized controlled trial. Therefore, stakeholder (patient participants, nurse care managers, and Parkinson disease (PD) specialists) perceptions of key intervention components merit evaluation to inform decisions about dissemination.

Methods: This multi-site study occurred in five southwest United States Veterans Health Administration medical centers. Stakeholders were surveyed on their perceptions of CHAPS including the CHAPS Assessment, CHAPS nurse care managers, the Siebens Domain Management Model ${ }^{\mathrm{TM}}$ (a practical clinical model), and the Siebens Health Care Notebook (Notebook) (self-care tool). Participants' electronic medical records were abstracted for perceptions of the Notebook. Statistical analysis software was used to provide summary statistics; open card sorting methodology was used to identify themes and attributes in qualitative data including usability of some components.
\end{abstract}

Results: Participants, overall, highly rated their medication self-management, acknowledged some challenges with the CHAPS self-care tools, reported knowledge of PD specialist follow-up and PD red flags, and rated CHAPS nurse care managers as helpful. Nurse care manager responses indicated the CHAPS Assessment and Program highly facilitated care of their patients. Most all PD specialists would refer other patients to CHAPS. Nurse care manager and PD specialist responses indicated improved participant management of their PD. Three themes emerged in participant perceptions of the Notebook: Notebook Assets (e.g., benefits and features-liked); Deferring Notebook Review (e.g., no time to review); and Reasons for Not Using (e.g., participant preference). Shared attributes regarding the Siebens Domain Management Model and Notebook usability, reported by nurse care managers, were user-friendly, person/patient-centered, and organized. Some challenges to their use were also reported.

(Continued on next page)

\footnotetext{
* Correspondence: kiconnor@ucla.edu

'Veterans Affairs Parkinson's Disease Research, Education and Clinical Center, Los Angeles, CA, USA

${ }^{2}$ UCLA David Geffen School of Medicine, Los Angeles, CA, USA

Full list of author information is available at the end of the article
}

(C) The Author(s). 2020 Open Access This article is licensed under a Creative Commons Attribution 4.0 International License, which permits use, sharing, adaptation, distribution and reproduction in any medium or format, as long as you give appropriate credit to the original author(s) and the source, provide a link to the Creative Commons licence, and indicate if changes were made. The images or other third party material in this article are included in the article's Creative Commons licence, unless indicated otherwise in a credit line to the material. If material is not included in the article's Creative Commons licence and your intended use is not permitted by statutory regulation or exceeds the permitted use, you will need to obtain permission directly from the copyright holder. To view a copy of this licence, visit http://creativecommons.org/licenses/by/4.0/. The Creative Commons Public Domain Dedication waiver (http://creativecommons.org/publicdomain/zero/1.0/) applies to the data made available in this article, unless otherwise stated in a credit line to the data. 


\begin{abstract}
(Continued from previous page)
Conclusions: Overall, stakeholder perceptions of the proactive nurse-led CHAPS intervention indicated its value in the care of individuals with PD. Responses about the CHAPS Assessment, Siebens Domain Management Model, and Notebook self-care tool signified their usefulness. Stakeholders' constructive suggestions indicated their engagement in CHAPS. These findings support CHAPS dissemination and contribute to research in care management.
\end{abstract}

Trial registration: ClinicalTrials.gov as NCT01532986, registered on January 13, 2012.

Keywords: Parkinson disease, Patient care management, Nursing process, Health communication, Case manager, Implementation, Dissemination

\section{Background}

Parkinson's disease (PD) care is evolving in response to the complexity of health-related problems that individuals experience $[1,2]$. These efforts are timely as the incidence of PD will increase with population aging [3, 4]. Furthermore, an international emphasis on age-friendly care is ongoing $[5,6]$. Recent studies have highlighted the importance of PD nurse specialists, as single point persons, to support patients and collaborate with PD specialists [1, 7]. However, a shortage of PD nurse specialists remains a barrier for many settings. Thus, a nurse-led care management intervention, Care Coordination for Health Promotion and Activities in Parkinson's Disease (CHAPS), was designed to improve care quality through addressing the broad array of PD health issues [8].

The randomized controlled trial of the 18-month CHAPS intervention demonstrated improved adherence to PD quality indicators compared to usual care [9]. The trial was conducted between 2012 and 2017 at five Veterans Health Administration medical centers in the Southwest United States. These centers provide care to men and women who have served in the United States military. In the trial, community-dwelling patient/participants were the unit of randomization. Because the CHAPS intervention improved care quality, feedback from stakeholders (patient/participants, CHAPS nurse care managers, and PD specialists) is needed [10]. Direct participant feedback helps confirm if care was person/ patient-centered [11-16]. Nurse care manager and PD specialist feedback provides insights on their engagement [17-19], likely representing buy-in required for adoption of new clinical approaches [20]. The purpose of this report is to describe stakeholder feedback on the CHAPS intervention and its components to inform decisions about CHAPS dissemination and contribute to research on improving PD care quality.

In brief, the CHAPS proactive care management intervention was led and provided by CHAPS nurse care managers oriented to PD care through a 10- to 40-h curriculum $[8,21-23]$. These nurse care managers administered the same CHAPS Assessment to each participant for identifying problems/topics, and their severity, by embedded algorithms (Additional file 1) [8]. During follow-up calls, these nurse care managers could refer to problem/topic-specific intervention protocols for coaching participants in solving problems (e.g., medication, coping/self-management, falls, access to care and services). Self-care tools provided to participants included a self-care notebook (Fig. 1) [24] with a personalized action plan (Additional file 2) and a copy of their CHAPS Assessment results to share with others as desired [23].

Given the multiple ways PD affects day-to-day living, an organizing framework was necessary to help standardize and guide care management. The Siebens Domain Management Model $^{\mathrm{mt}}[25,26]$ was chosen as a synthesis of nursing [27, 28], biomedical, biopsychosocial [29], and biopsycho-ecological models [30]. It applies to any individual with any disease(s) or chronic/enduring health condition(s) in any care setting $[8,25]$ and has been shown to improve clinical outcomes [31-33]. This person/patient-centered care framework organizes individuals' health-related strengths, problems, and topics into four orderly domains for following over time: I Medical/Surgical Issues, II Mental Status/Emotions/Coping, III Physical Function, and IV Living Environment (๑ Hilary C Siebens MD 2005) [23, 25, 31-37].

To use the four-domain concept with individuals and promote communication and self-management, each domain has a plain phrase name. These were determined with input from health literacy experts for corresponding sections in the Siebens Health Care Notebook (Notebook) [24, 25] (Fig. 1). This Notebook is a paper repository of health-related reminders and personalized education (after visit sheets, medication lists, education sheets, etc.). Notebooks have been used in randomized trials [38-40] and in quality improvement studies [41, 42] to assist self-care. Patient-held print records, like notebooks, have been noted as part of learning self-care in care transitions $[43,44]$ and care for enduring health conditions [45]. Recently, Notebook recipients treated for breast cancer, with difficulties in memory and thinking, endorsed it as a helpful tool in self-care [46].

We chose to assess usability of the Siebens Domain Management Model and the Notebook to inform 


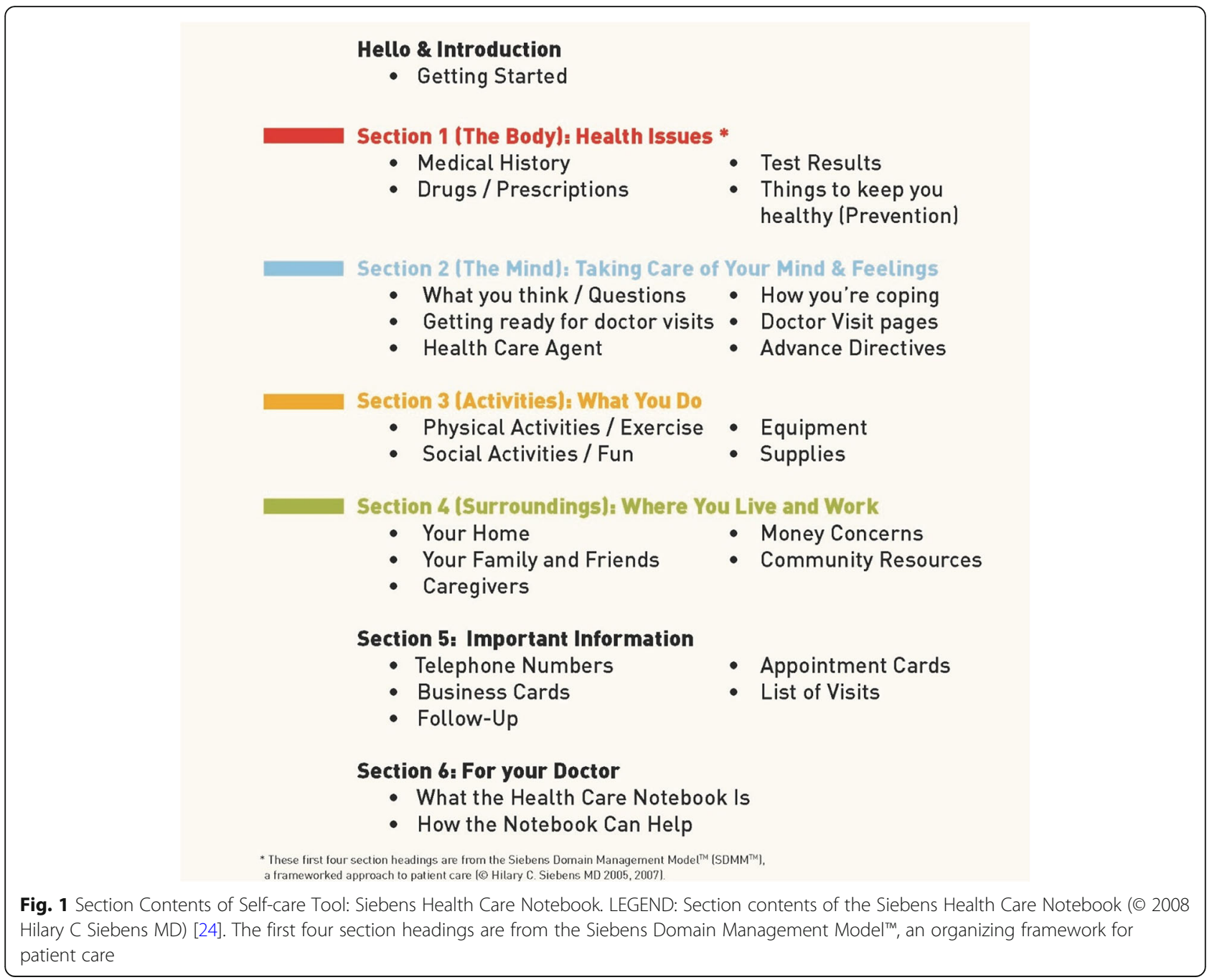

decisions on dissemination. Usability testing had been helpful in finalizing the CHAPS Assessment in a previous pilot study, funded by Veterans Affairs Health Services Research and Development-Nurse Research Initiative (2008-2010). A research assistant had administered a 10-item usability survey about the drafted CHAP S Assessment to a convenience sample of 7 (28\%) of 25 participants (unpublished KIC). The Assessment was found to be comprehensive, informative, and brought problems and topics to light that needed consideration, and question content was considered appropriate and not difficult. Some sensitive sections (e.g., incontinence, sexuality) required more explanation before questions were asked; thus, scripts for these sections were modified and the CHAPS Assessment was finalized.

\section{Methods}

Aims were to evaluate: (1) participants' knowledge of PD self-care and helpfulness of nurse care managers; (2) participants' perceptions of the CHAPS Assessment; (3) participants' responses to the health care Notebook; (4) CHAPS nurse care manager and PD specialist knowledge, beliefs, and attitudes about CHAPS and their perceptions of participants' self-management; and (5) the usability of the Siebens Domain Management Model and the Notebook from the nurse care managers' perspective.

\section{Setting and eligible participants}

This study was conducted within the intervention arm of the CHAPS trial [9]. A total of 140 intervention participants received care management over an 18-month period. CHAPS nurse care manager staffing was about 125 participants per one full time employee equivalent. Routine assessments were the CHAPS Assessment, 6month follow-ups, and annual reassessments. All participants received the CHAPS Assessment, averaging 120 min (standard deviation (SD) 78) requiring 2.1 encounters (SD 1.6, median 2.0) (i.e., participant/nurse care manager interactions). Annual reassessments $(n=29)$, 
designed to be briefer, averaged $32 \mathrm{~min}$ (SD 34) requiring 1.1 encounters (SD 0.4, median 1.0). Follow-up encounters were interactions done at the discretion of the nurse care manager and scheduled in collaboration with the participant after the CHAPS Assessment. These encounters, inclusive of the 6-month follow-ups, were an average of $28 \mathrm{~min}$ (SD 20) and varied from none to several per participant, averaging 3.3 encounters (SD 1.3, median 4.0) [23].

Participants' had a mean age of 69.4 years (SD 10.3) and were $95.0 \%$ male. Self-identified race other than Caucasian was $23.6 \%$. The mean Health Utilities Index 3 , a measure of health-related quality of life (-1 to 1 , higher score is better), was 0.45 (SD 0.31), findings similar to a Veteran Health Administration study [47] and lower than 0.61 in another community dwelling population [48]. Among the 31 problems/topics potentially identified through the CHAPS Assessment, 74.3\% of participants had Motor-related, 35.7\% Cognitive, 56.4\% Functional limitations, and $75.7 \%$ Falls (inclusive of risk factors) problems/topics [23].

Stakeholder responses were gathered at end of the trial. All participants were included for the evaluation of participant responses to the Notebook. A convenience sample of participants, enrolled toward the end of the trial, provided perceptions of the CHAPS intervention [8]. CHAPS nurse care managers and PD specialists surveyed for their perceptions were not considered subjects per Veterans Health Administration Institutional Review Boards, November 9, 2011.

\section{Data}

This report used quantitative and qualitative response data gathered through either anonymous paper surveys or research assistant-administered telephone surveys. The research assistant and project manager abstracted participant Notebook perceptions, documented by CHAPS nurse care managers. All data were stored on a secure health services research server.

\section{Participant surveys}

The participant survey was a 17 -item telephone survey about the CHAPS intervention. Thirteen survey questions addressed the Care Transition Program's Four Pillars adapted to outpatient PD care: (1) Medication self-management, (2) Use of dynamic patient-centered record, (3) PD specialist and nurse care manager followup, and (4) Parkinson disease red flags. Additional questions addressed helpfulness of the nurse care manager. All items were adapted from the Care Transition Measure (CTM-15) [49] and their use in a dementia care management program [50]. Response choices were from 1 (strongly disagree) to 5 (strongly agree). Three openended questions elicited comments about the CHAPS
Assessment (their overall impressions, what they liked best, and what they liked least) and one other elicited any additional participant comments.

\section{Nurse care manager and PD specialist surveys}

The CHAPS nurse care managers and PD specialists' surveys were 14-item anonymous paper surveys about the CHAPS intervention. These were adapted from a previous program evaluation survey [50] that assessed knowledge, beliefs, and attitudes [51]. Questions were organized into five constructs: Knowledge/Understanding, Self-confidence, Clinical Appropriateness, Participant Self-management Improvement, and Endorsement. Three of the 14 questions were stated in the negative to allow for response choices to be in both the "agree" and "disagree" categories to help minimize agreement bias. In presenting results, responses to these 3 questions were rescored so all responses are reported in the same direction. An open-ended question elicited comments about how CHAPS could be improved. For PD specialists, additional questions asked about awareness of the Siebens Domain Management Model in the CHAPS documentation. If they responded "yes," then they were asked if they felt it was a helpful way to organize participants' problems/issues (yes, no, unsure). Also, PD specialists were asked if the participants brought Notebooks to their appointments (yes, no, unsure).

Usability - how a concept or care tool fits a particular purpose [52] - of the Siebens Domain Management Model and the Notebook was obtained from CHAPS nurse care managers. Two usability surveys, administered via telephone by a research assistant, were adapted from a web accessibility survey [53] that had been pilot tested during the development of the CHAPS Assessment.

\section{Analyses}

SAS 9.4 statistical analysis software (SAS Institute, Inc., Cary, North Carolina) was used to provide descriptive summary statistics (i.e., frequencies and percentages). Survey rating responses for participants, CHAPS nurse care managers, and PD specialists were reported as counts and percentages for individual items.

Open card sorting was used for grouping free text comments from participants about the Notebook and comments provided by stakeholders in the surveys. Two researchers (KIC, HCS) together examined comments for word similarities (generalizations in semantics, analogies, and metaphors), distilled them into items, and sorted these items into groups that were not pre-specified. They used their knowledge of healthcare and language to refine the sorts. For items on which they disagreed, they either came to a collaborative decision or placed the item into an "Other" 
category. Finally, they created names for themes and attributes of related items [54, 55].

\section{Results}

Participant survey responses

All 28 (100\%) participants agreed to take part in the 17item survey. Overall, participants indicated highly they could self-manage medications (Pillar 1). Of the participants who recalled the three self-care tools (Notebook, CHAPS Assessment, My Action Plan) (Pillar 2), responses about usefulness varied. Participants rated highly knowing when to follow-up with the PD specialist (Pillar 3) and awareness of PD red flags (Pillar 4). Of participants who recalled speaking with CHAPS nurse care managers, responses indicated their helpfulness. Participants noted being able to talk to them and getting help in safety, activities, and self-care (Table 1).

A total of 20 participants provided qualitative responses $(n=32)$ about their overall impressions of the CHAPS Assessment. Three themes emerged: (1) Benefit to the Assessment (e.g., helpful/appreciative, covered all the issues, impressed, pleased with advice, and opportunity to reflect on PD); (2) Nature of interaction (e.g., caring, pleased with interaction, and confused by some assessment questions); and (3) Information gathering (e.g., comprehensive is good, providers need data). Four general observations were: recommend services, education is needed, knowledge needed early on that PD is complex, and tracking symptoms and treatment results are important.

\section{Participant feedback about the Notebook}

Of the 140 participants who received Notebooks, 21 received no follow-up nurse care manager contact. A total of $67(59.8 \%)$ participants had qualitative feedback documented on the Notebook. Three themes emerged: Notebook assets ( $n=97$ items), Deferring Notebook review ( $n=28$ items), and Reasons not using Notebook ( $n=19$ items) (Table 2). Additionally, participants reported care partner responses to the Notebook: Impressed ( $n=4$, e.g., very happy to have it) and Helpful/organized ( $n=4$, e.g., can take it and go).

\section{Nurse care manager survey responses}

Seven of eight CHAPS nurse care managers (one unavailable) provided survey responses. Regarding the construct Knowledge/Understanding, nurse care manager responses uniformly indicated the CHAPS Assessment and Program facilitated their care of patients. They had mixed ratings relating to the influence of CHAPS on their Self-Confidence. Responses affirmed the Clinical Appropriateness in CHAPS. On Participant's SelfManagement Improvement, over half of the nurse care manager responses reflected improvements (Table 3).
Four of seven CHAPS nurse care managers provided comments $(n=17)$ to the open-ended question about how to improve CHAPS. Five themes emerged: (1) Shorten CHAPS Assessment, (2) Add care management software, (3) Provide more practice (with the Siebens Domain Management Model, huddles with PD specialists, and readiness to learn techniques), (4) Offer option of face-to-face Assessments (in clinic or via clinical video telehealth), and (5) Maintain consistent nurse care manager staffing (e.g., to build trust, facilitate collaboration, foster behavioral change, and support Notebook use). Additional comments endorsed CHAPS: positively impacted patients, supported patient-nurse care manager partnership, ideal for other enduring conditions, merits dissemination, and can incorporate future advances.

\section{PD specialist survey responses}

A total of 10 of 12 PD specialists responded to the provider survey. Their responses indicated the CHAPS Assessment and Program facilitated patient care (see Knowledge/Understanding construct) (Table 4). Additionally, responses affirmed the Clinical Appropriateness of CHAPS, and endorsed Participant's Self-Management Improvement. Overall, PD specialists reported they would refer their other patients to CHAPS.

All 10 PD specialists provided comments about CHAP S. Two themes emerged: (1) CHAPS nurse care manager/PD specialist collaboration (e.g., nurse care manager on site, reinforce consistent periodic conference telephone calls, prioritize topics for discussion, and notify PD specialist of CHAPS note availability) and (2) Helpfulness of nurse care managers (e.g., checking on patient needs, re-emphasizing clinic discussions, spending more time talking to patients than is available in clinic, facilitating completion of advance directives, coaching about long-term care decision-making, obtaining benefits and durable medical equipment, and assisting decision-making on ordering driving evaluations).

\section{Nurse care manager and PD specialist feedback on the Siebens domain management model}

CHAPS nurse care managers $(n=7)$ provided 84 comments in the usability survey about the Siebens Domain Management Model. Open card sorting yielded two themes: Facilitators for using the model ( $n=55$ items) and Challenges in using the model ( $n=29$ items) (Table 5). Two nurse care managers stated there was nothing they disliked about the model. In rating how easy or hard the model was to understand, responses were: very easy $(n=2)$, easy $(n=2)$, easy/neutral $(n=1)$, and hard $(n=2)$. As for recommending the model to a colleague, responses were the following: yes $(n=3)$, maybe $(n=3)$, and no $(n=1)$. 
Table 1 Participant responses to telephone survey about CHAPS $(n=28)$

\begin{tabular}{|c|c|c|c|c|c|c|}
\hline Pillars and Specific Questions & $\begin{array}{l}\text { Strongly } \\
\text { Disagree }\end{array}$ & $\begin{array}{l}\text { Disagree } \\
\text { n (\%) }\end{array}$ & $\begin{array}{l}\text { Not } \\
\text { Sure } \\
\mathrm{n} \\
(\%)\end{array}$ & $\begin{array}{l}\text { Agree } \\
\mathrm{n}(\%)\end{array}$ & $\begin{array}{l}\text { Strongly } \\
\text { Agree } \\
\text { n (\%) }\end{array}$ & $\begin{array}{l}\text { Don't } \\
\text { recall } \\
\text { n (\%) }\end{array}$ \\
\hline \multicolumn{7}{|l|}{ Medication Self-management (Pillar $1^{\mathrm{a}}$ ) } \\
\hline I know how to take my PD medications. & - & $1(3.6)$ & - & $\begin{array}{l}24 \\
(85.7)\end{array}$ & $3(10.7)$ & - \\
\hline I know what my PD medications are for. & - & $1(3.6)$ & $\begin{array}{l}2 \\
(7.1)\end{array}$ & $\begin{array}{l}23 \\
(82.1)\end{array}$ & $2(7.1)$ & - \\
\hline I know the side effects of my PD medications ${ }^{b}$. & - & $2(7.7)$ & $\begin{array}{l}3 \\
(11.5)\end{array}$ & $\begin{array}{l}20 \\
(76.9)\end{array}$ & $1(3.8)$ & - \\
\hline \multicolumn{7}{|l|}{ Use of Dynamic Patient-centered Record (Pillar 2) } \\
\hline $\begin{array}{l}\text { The Siebens Health Care Notebook that the CHAPS Nurse Care Manager mailed to } \\
\text { me, helps my doctors, team, and me to take better care of myself. }\end{array}$ & - & $9(32.1)$ & $\begin{array}{l}7 \\
(25.0)\end{array}$ & $\begin{array}{l}8 \\
(28.6)\end{array}$ & $2(7.1)$ & $2(7.1)$ \\
\hline $\begin{array}{l}\text { I felt my CHAPS Assessment Summary, located in the back of my personal health care } \\
\text { notebook, was useful. }\end{array}$ & - & $5(17.9)$ & $\begin{array}{l}8 \\
(28.6)\end{array}$ & $\begin{array}{l}4 \\
(14.3)\end{array}$ & $1(3.6)$ & $\begin{array}{l}10 \\
(35.7)\end{array}$ \\
\hline I felt My Action Plan, located in my personal health notebook, was useful. & - & $4(14.3)$ & $\begin{array}{l}10 \\
(35.7)\end{array}$ & $\begin{array}{l}3 \\
(10.7)\end{array}$ & - & $\begin{array}{l}11 \\
(39.3)\end{array}$ \\
\hline \multicolumn{7}{|l|}{ Parkinson disease Specialist Follow-up (Pillar 3) } \\
\hline I know when to follow up with my PD doctor. & - & $2(7.1)$ & $\begin{array}{l}2 \\
(7.1)\end{array}$ & $\begin{array}{l}24 \\
(85.7)\end{array}$ & - & - \\
\hline \multicolumn{7}{|l|}{ Parkinson disease Red Flags (Pillar 4) } \\
\hline I know symptoms I should watch for to monitor my Parkinson disease (PD) condition. & - & $1(3.6)$ & $\begin{array}{l}2 \\
(7.1)\end{array}$ & $\begin{array}{l}23 \\
(82.1)\end{array}$ & $2(7.1)$ & - \\
\hline I know what I should do if my PD symptoms get worse. & - & $2(7.1)$ & $\begin{array}{l}1 \\
(3.6)\end{array}$ & $\begin{array}{l}24 \\
(85.7)\end{array}$ & $1(3.6)$ & - \\
\hline \multicolumn{7}{|l|}{ Additional questions addressing the Helpfulness of Nurse Care Manager } \\
\hline I felt I could talk to my CHAPS Nurse Care Manager about my condition. & - & $2(7.1)$ & $\begin{array}{l}3 \\
(10.7)\end{array}$ & $\begin{array}{l}19 \\
(67.9)\end{array}$ & $3(10.7)$ & $1(3.6)$ \\
\hline The CHAPS Nurse Care Manager helped me be as safe and active as I can be. & - & $1(3.6)$ & $\begin{array}{l}5 \\
(17.9)\end{array}$ & $\begin{array}{l}17 \\
(60.7)\end{array}$ & $3(10.7)$ & $2(7.1)$ \\
\hline I felt my CHAPS Nurse Care Manager helped me manage my PD. & - & $2(7.1)$ & $\begin{array}{l}6 \\
(21.4)\end{array}$ & $\begin{array}{l}17 \\
(60.7)\end{array}$ & $2(7.1)$ & $1(3.6)$ \\
\hline I felt my CHAPS Nurse Care Manager helped me manage my health overall. & - & $3(10.7)$ & $\begin{array}{l}4 \\
(14.3)\end{array}$ & $\begin{array}{l}18 \\
(64.3)\end{array}$ & $2(7.1)$ & $1(3.6)$ \\
\hline
\end{tabular}

CHAPS Care Coordination for Health Promotion and Activities in Parkinson's Disease $P D$ Parkinson's disease

a The four pillar names are adapted from the Care Transition Program, Coleman E, J Am Geriatr Soc 2004; 52:1817

b 2 responses were missing

Six of ten PD specialists were aware of the Siebens Domain Management Model, used in the CHAPS nurse care manager documentation. Four felt the model was a helpful method to organize patients' problems, two were unsure, and none provided negative feedback.

\section{Nurse care manager and PD specialist feedback about the Notebook}

CHAPS nurse care managers $(n=7)$ provided 74 comments in the usability survey about the Notebook. Open card sorting yielded two themes: Facilitators for coaching about the Notebook ( $n=46$ items) and Challenges to coaching about the Notebook ( $n=28$ items) (Table 6). Additionally, two nurse care managers stated there was nothing they disliked about the Notebook. For ratings of how easy or hard it was to understand the Notebook, responses were very easy $(n=6)$ and neutral $(n=1)$. As for recommending the Notebook to a colleague, responses were yes $(n=4)$, no $(n=2)$, and it depends on the patient population $(n=1)$. Two nurse care managers recommended the Notebook to others outside the study.

Two PD specialists' reported participants brought their Notebooks to appointments, 7 reported not seeing Notebooks, and one was not sure. Two PD specialists reported interacting with the Notebook and said something positive to participants about their use of it. Additional comments included: learned something useful from the Notebook, it helped in the care of these participants, and believed participants found it useful or helpful as did care partners. 
Table 2 Participant perceptions of the Siebens Health Care Notebook

\begin{tabular}{|c|c|c|}
\hline Themes & Attributes & Items (n) \\
\hline \multirow[t]{3}{*}{$\begin{array}{l}\text { Notebook assets } \\
(n=97)\end{array}$} & $\begin{array}{l}\text { Notebook benefits } \\
(n=42)\end{array}$ & $\begin{array}{l}\text { Helpful (10) } \\
\text { Informative (8) } \\
\text { Tool for organizing (7) } \\
\text { Very useful (6) } \\
\text { Personalized (5) } \\
\text { Communicating with providers (3) } \\
\text { Easy format to read (2) } \\
\text { Doctor looked through it (1) }\end{array}$ \\
\hline & $\begin{array}{l}\text { Notebook features liked } \\
(n=37)\end{array}$ & $\begin{array}{l}\text { Education sheets (10) } \\
\text { Medication list (6) } \\
\text { Organized by sections (6) } \\
\text { Doctor visit sheet (5) } \\
\text { CHAPS Assessment (3) } \\
\text { A lot of information (2) } \\
\text { Action tracking (2) } \\
\text { Serves as a review (1) } \\
\text { My Action Plan (1) } \\
\text { Business card holder (1) }\end{array}$ \\
\hline & $\begin{array}{l}\text { Affirmative feelings } \\
(n=18)\end{array}$ & $\begin{array}{l}\text { Impressed (5) } \\
\text { Likes (4) } \\
\text { Appreciative (3) } \\
\text { Nice (3) } \\
\text { Looking forward to using (2) } \\
\text { Notebook-type person (1) }\end{array}$ \\
\hline \multirow[t]{3}{*}{$\begin{array}{l}\text { Reasons for participants deferring Notebook review } \\
(n=28)\end{array}$} & $\begin{array}{l}\text { No time to review } \\
(n=17)\end{array}$ & \\
\hline & $\begin{array}{l}\text { Participant preference } \\
(n=6)\end{array}$ & $\begin{array}{l}\text { Wants to review later (3) } \\
\text { Currently not using the Notebook (3) }\end{array}$ \\
\hline & $\begin{array}{l}\text { Barriers to reviewing } \\
(n=5)\end{array}$ & $\begin{array}{l}\text { Vision too poor to read (1) } \\
\text { Lost glasses (1) } \\
\text { Lost Notebook (1) } \\
\text { Feels depressed (1) } \\
\text { Participant appears disorganized (1) }\end{array}$ \\
\hline \multirow[t]{2}{*}{$\begin{array}{l}\text { Reasons for not using Notebook } \\
(n=19)\end{array}$} & $\begin{array}{l}\text { Participant preference } \\
(n=12)\end{array}$ & $\begin{array}{l}\text { Not interested (6) } \\
\text { Can already remember everything (2) } \\
\text { Do not need anything (2) } \\
\text { Too busy (2) }\end{array}$ \\
\hline & $\begin{array}{l}\text { Notebook characteristics } \\
(n=7)\end{array}$ & $\begin{array}{l}\text { Cumbersome (4) } \\
\text { Requires writing (2) } \\
\text { Dislikes print material (1) }\end{array}$ \\
\hline
\end{tabular}

${ }^{\mathrm{a}}$ Benefits - defined as fulfillment of needs

\section{Discussion}

Stakeholder responses to several surveys provided insights on multiple aspects of the CHAPS intervention. These surveys gave stakeholders a voice. Participants reported frequent awareness of key aspects of their PD self-care, benefits of the CHAPS Assessment, and helpfulness of CHAPS nurse care managers. PD specialists and nurse care managers noted improvements in participant self-management, especially in their medication regime and how to manage their PD. The nurse care managers acknowledged CHAPS helped in the care of their patients. PD specialists found the nurse care manager's role helpful. Feedback on the Siebens Domain Management Model and Notebook usability identified their value and shared attributes of person/patient-centeredness, user-friendliness, and organization.
CHAPS nurse care managers' and PD specialists' suggestions for CHAPS likely indicated their engagement and buy-in, necessities for successful intervention dissemination [17-19]. The CHAPS Assessment could be shorter, nurse care manager availability could be more consistent than occurred during the trial, and closer collaboration could be facilitated between nurse care managers and PD specialists. Nurse care managers could be offered additional practice on the Siebens Domain Management Model (e.g., placing problems/topics in domains) and Notebook coaching (e.g., motivational interviewing, readiness to learn techniques).

Generalizability of these findings may be limited to the mostly male veteran population and the Veterans Health Administration healthcare setting. However, individuals 
Table 3 Nurse care manager responses to survey about CHAPS $(n=7)$

\begin{tabular}{|c|c|c|c|c|c|}
\hline Constructs and Specific Questions & $\begin{array}{l}\text { Strongly } \\
\text { disagree } \\
\mathrm{n}(\%)\end{array}$ & $\begin{array}{l}\text { Disagree } \\
\text { n (\%) }\end{array}$ & $\begin{array}{l}\text { Undecided } \\
\text { /neutral } \\
\text { n (\%) }\end{array}$ & $\begin{array}{l}\text { Agree } \\
\text { n (\%) }\end{array}$ & $\begin{array}{l}\text { Strongly } \\
\text { agree } \\
\text { n (\%) }\end{array}$ \\
\hline \multicolumn{6}{|l|}{ Knowledge/Understanding } \\
\hline $\begin{array}{l}\text { CHAPS Assessments, administered by CHAPS Nurse Care Managers, have provided } \\
\text { information that will improve how I take care of my patients with Parkinson's disease } \\
\text { (PD). } \\
\text { (Knowledge (about care)) }\end{array}$ & - & - & $1(14.3)$ & $\begin{array}{l}2 \\
(28.6)\end{array}$ & $4(57.1)$ \\
\hline $\begin{array}{l}\text { CHAPS Assessments have taught me something that I can use in my care of other } \\
\text { patients with chronic disease. (Knowledge (about care)) }\end{array}$ & - & - & - & $\begin{array}{l}5 \\
(71.4)\end{array}$ & $2(28.6)$ \\
\hline $\begin{array}{l}\text { CHAPS Assessments have provided me with information that is relevant to the care of } \\
\text { my patients with PD. } \\
\text { (Belief (relevance)) }\end{array}$ & - & - & - & $\begin{array}{l}3 \\
(42.9)\end{array}$ & $4(57.1)$ \\
\hline $\begin{array}{l}\text { The CHAPS Program provides recommendations that are useful to help me care for my } \\
\text { patients with PD. } \\
\text { (Belief (usefulness)) }\end{array}$ & - & - & $1(14.3)$ & $\begin{array}{l}2 \\
(28.6)\end{array}$ & $4(57.1)$ \\
\hline \multicolumn{6}{|l|}{ Self-Confidence } \\
\hline $\begin{array}{l}\text { The CHAPS Program has impacted my degree of confidence with clinical deci-sions in- } \\
\text { volving Parkinson's disease care. (Confidence (in self)) }\end{array}$ & - & - & $3(42.9)$ & $\begin{array}{l}1 \\
(14.3)\end{array}$ & $3(42.9)$ \\
\hline \multicolumn{6}{|l|}{ Clinical Appropriateness } \\
\hline $\begin{array}{l}\text { CHAPS Assessments have provided diagnostic information that I agree with. (Belief } \\
\text { (agreement)) }\end{array}$ & - & - & $1(14.3)$ & $\begin{array}{l}3 \\
(42.9)\end{array}$ & $3(42.9)$ \\
\hline $\begin{array}{l}\text { CHAPS Assessments have recommended care suggestions that I agree with. (Belief } \\
\text { (agreement)) }\end{array}$ & - & $1(14.3)$ & $1(14.3)$ & $\begin{array}{l}2 \\
(28.6)\end{array}$ & $3(42.9)$ \\
\hline $\begin{array}{l}\text { The CHAPS Assessment and CHAPS Nurse Care Managers pay attention to detail and } \\
\text { are thorough. } \\
\text { (Belief (thoroughness)) }\end{array}$ & - & $1(14.3)$ & - & $\begin{array}{l}3 \\
(42.9)\end{array}$ & $3(42.9)$ \\
\hline \multicolumn{6}{|l|}{ Participant's Self-Management Improvement } \\
\hline $\begin{array}{l}\text { My patient(s) now have a better understanding of their medication regimen (purpose, } \\
\text { how to take, and side effects). } \\
\text { (Belief (understanding)) }\end{array}$ & - & - & $2(28.6)$ & $\begin{array}{l}3 \\
(42.9)\end{array}$ & $2(28.6)$ \\
\hline $\begin{array}{l}\text { My patient(s) now have a better understanding of how to manage their Parkinson's } \\
\text { disease. } \\
\text { (Belief (understanding)) }\end{array}$ & - & - & $2(28.6)$ & $\begin{array}{l}3 \\
(42.9)\end{array}$ & $2(28.6)$ \\
\hline $\begin{array}{l}\text { My patient(s) now are better at following through on laboratory tests and } \\
\text { appointments. } \\
\text { (Belief (follow-through)) }\end{array}$ & - & - & $3(42.9)$ & $\begin{array}{l}3 \\
(42.9)\end{array}$ & $1(14.3)$ \\
\hline $\begin{array}{l}\text { My patient(s) are better able to identify signs and symptoms that indicate a risk for } \\
\text { being admitted to the hospital. } \\
\text { (Belief (identifying risks)) }\end{array}$ & - & $1(14.3)$ & $3(42.9)$ & $\begin{array}{l}3 \\
(42.9)\end{array}$ & - \\
\hline $\begin{array}{l}\text { Patient understands and manages his/her Siebens HealthCare Notebook. } \\
\text { (Belief (Notebook management)) }\end{array}$ & - & $2(28.6)$ & $1(14.3)$ & $\begin{array}{l}3 \\
(42.9)\end{array}$ & $1(14.3)$ \\
\hline \multicolumn{6}{|l|}{ Endorsement } \\
\hline $\begin{array}{l}\text { CHAPS Assessments and Nurse Care Management have encouraged me to refer my } \\
\text { other patients with PD to the CHAPS Program }{ }^{\text {a }} \\
\text { (Attitude (behavior)) }\end{array}$ & - & $1(16.7)$ & $1(16.7)$ & $\begin{array}{l}2 \\
(33.3)\end{array}$ & $2(33.3)$ \\
\hline
\end{tabular}

CHAPS Care Coordination for Health Promotion and Activities in Parkinson's Disease

$P D$ Parkinson's disease

a One response was missing

with PD in other health settings are likely to have similar problems that could benefit from nurse care managers, guided by outpatient structured care management. Sample sizes of each stakeholder group were small; nonetheless, feedback provided rich insights. Participant knowledge and understanding about PD may have been influenced by care received outside of CHAPS, even though participants were instructed to answer survey questions in relation to their experience with CHAPS. Limited follow-up during implementation may have affected CHAPS nurse care manager perceptions of participants' self-management. 
Table 4 Parkinson disease specialist responses to survey about CHAPS $(n=10)$

\begin{tabular}{|c|c|c|c|c|c|}
\hline Constructs and Specific Questions & $\begin{array}{l}\text { Strongly } \\
\text { disagree } \\
\mathrm{n}(\%)\end{array}$ & $\begin{array}{l}\text { Disagree } \\
\text { n (\%) }\end{array}$ & $\begin{array}{l}\text { Undecided } \\
\text { /neutral } \\
\text { n (\%) }\end{array}$ & $\begin{array}{l}\text { Agree } \\
\text { n (\%) }\end{array}$ & $\begin{array}{l}\text { Strongly } \\
\text { agree } \\
\text { n (\%) }\end{array}$ \\
\hline \multicolumn{6}{|l|}{ Knowledge/Understanding } \\
\hline $\begin{array}{l}\text { CHAPS Assessments, administered by CHAPS Nurse Care Managers, have provided } \\
\text { information that will improve how I take care of my patients with Parkinson's disease } \\
\text { (PD). } \\
\text { (Knowledge (about care)) }\end{array}$ & - & $1(10.0)$ & $1(10.0)$ & $\begin{array}{l}5 \\
(50.0)\end{array}$ & $3(30.0)$ \\
\hline $\begin{array}{l}\text { CHAPS Assessments have taught me something that I can use in my care of other } \\
\text { patients with chronic disease. } \\
\text { (Knowledge (about care)) }\end{array}$ & $1(10.0)$ & - & $2(20.0)$ & $\begin{array}{l}4 \\
(40.0)\end{array}$ & $3(30.0)$ \\
\hline $\begin{array}{l}\text { CHAPS Assessments have provided me with information that is relevant to the care of } \\
\text { my patients with PD. } \\
\text { (Belief (relevance)) }\end{array}$ & - & - & $1(10.0)$ & $\begin{array}{l}5 \\
(50.0)\end{array}$ & $4(40.0)$ \\
\hline $\begin{array}{l}\text { The CHAPS Program provides recommendations that are useful to help me care for my } \\
\text { patients with PD. } \\
\text { (Belief (usefulness)) }\end{array}$ & - & - & $4(40.0)$ & $\begin{array}{l}1 \\
(10.0)\end{array}$ & $5(50.0)$ \\
\hline \multicolumn{6}{|l|}{ Self-Confidence } \\
\hline $\begin{array}{l}\text { The CHAPS Program has impacted my degree of confidence with clinical decisions } \\
\text { involving Parkinson's disease care. } \\
\text { (Confidence (in self)) }\end{array}$ & - & $1(10.0)$ & $3(30.0)$ & $\begin{array}{l}5 \\
(50.0)\end{array}$ & $1(10.0)$ \\
\hline \multicolumn{6}{|l|}{ Clinical Appropriateness } \\
\hline $\begin{array}{l}\text { CHAPS Assessments have provided diagnostic information that I agree with. } \\
\text { (Belief (agreement)) }\end{array}$ & - & - & $2(20.0)$ & $\begin{array}{l}5 \\
(50.0)\end{array}$ & $3(30.0)$ \\
\hline $\begin{array}{l}\text { CHAPS Assessments have recommended care suggestions that I agree with. } \\
\text { (Belief (agreement)) }\end{array}$ & - & - & $1(10.0)$ & $\begin{array}{l}5 \\
(50.0)\end{array}$ & $4(40.0)$ \\
\hline $\begin{array}{l}\text { The CHAPS Assessment and CHAPS Nurse Care Managers pay attention to detail and } \\
\text { are thorough. } \\
\text { (Belief (thoroughness)) }\end{array}$ & - & - & $1(10.0)$ & $\begin{array}{l}1 \\
(10.0)\end{array}$ & $8(80.0)$ \\
\hline \multicolumn{6}{|l|}{ Participant's Self-Management Improvement } \\
\hline $\begin{array}{l}\text { My patient(s) now have a better understanding of their medication regimen (purpose, } \\
\text { how to take, and side effects). } \\
\text { (Belief (understanding)) }\end{array}$ & - & - & $1(10.0)$ & $\begin{array}{l}5 \\
(50.0)\end{array}$ & $4(40.0)$ \\
\hline $\begin{array}{l}\text { My patient(s) now have a better understanding of how to manage their Parkinson's } \\
\text { disease. } \\
\text { (Belief (understanding)) }\end{array}$ & - & - & $1(10.0)$ & $\begin{array}{l}4 \\
(40.0)\end{array}$ & $5(50.0)$ \\
\hline $\begin{array}{l}\text { My patient(s) now are better at following through on laboratory tests and } \\
\text { appointments. } \\
\text { (Belief (follow-through)) }\end{array}$ & - & - & $4(40.0)$ & $\begin{array}{l}3 \\
(30.0)\end{array}$ & $3(30.0)$ \\
\hline $\begin{array}{l}\text { My patient(s) are better able to identify signs and symptoms that indicate a risk for } \\
\text { being admitted to the hospital. } \\
\text { (Belief (identifying risk)) }\end{array}$ & - & - & $3(30.0)$ & $\begin{array}{l}6 \\
(60.0)\end{array}$ & $1(10.0)$ \\
\hline $\begin{array}{l}\text { Patient understands and manages his/her Siebens HealthCare Notebook. } \\
\text { (Belief (Notebook management)) }\end{array}$ & - & - & $5(50.0)$ & $\begin{array}{l}5 \\
(50.0)\end{array}$ & - \\
\hline \multicolumn{6}{|l|}{ Endorsement } \\
\hline $\begin{array}{l}\text { CHAPS Assessments and Nurse Care Management have encouraged me to refer my } \\
\text { other patients with PD to the CHAPS Program. } \\
\text { (Attitude (behavior)) }\end{array}$ & - & - & $1(10.0)$ & $\begin{array}{l}2 \\
(20.0)\end{array}$ & $7(70.0)$ \\
\hline
\end{tabular}

CHAPS Care Coordination for Health Promotion and Activities in Parkinson's Disease

$P D$ Parkinson's disease

\section{Implications}

The nurse care manager role, as defined in the CHAPS Program, may help health care organizations improve their care quality of individuals with PD. First, CHAPS is one means for overcoming the shortage of PD nurse specialists, which is akin to initiatives like ParkinsonNet that focus on improving professionals' education and training [2]. Second, as participants reported CHAPS nurse care managers were helpful, these interactions may contribute to care quality comparable to findings in our dementia care management study [56]. Third, nurse care managers, using the proactive standardized CHAPS 
Table 5 Usability survey themes and responses from nurse care managers ( $n=7)$ about the Siebens Domain Management Model

\begin{tabular}{|c|c|c|}
\hline Themes & Attributes & Items (n) \\
\hline \multirow[t]{4}{*}{$\begin{array}{l}\text { Facilitators for Using the SDMM } \\
(n=55)\end{array}$} & $\begin{array}{l}\text { User-friendly } \\
(n=19)\end{array}$ & $\begin{array}{l}\text { Able to put SDMM into action (6) } \\
\text { Understandable for nurses (4) } \\
\text { Simplifies information (4) } \\
\text { Understandable for patient and provider (2) } \\
\text { Helps clinicians think things through (2) } \\
\text { Powerful tool (1) }\end{array}$ \\
\hline & $\begin{array}{l}\text { Person/Patient-centered } \\
(n=16)\end{array}$ & $\begin{array}{l}\text { Looks comprehensively at a person's health (4) } \\
\text { Domains and Notebook usable by variety of patients (3) } \\
\text { Thoughtful and detailed about the patient (3) } \\
\text { Makes understanding a variety of patients easier (3) } \\
\text { Reflects nursing's holistic view (1) } \\
\text { Helps physicians to look at whole picture (1) } \\
\text { Patients benefit when SDMM used (1) }\end{array}$ \\
\hline & $\begin{array}{l}\text { Organized } \\
(n=11)\end{array}$ & $\begin{array}{l}\text { Four domains are organized (4) } \\
\text { The way } 4 \text { domains are separated (2) } \\
\text { Good theory in organizing patients' problems (2) } \\
\text { Concise (1) } \\
\text { Clear (1) } \\
\text { Easier to categorize everything (1) }\end{array}$ \\
\hline & Helpful for documentation $(n=9)$ & $\begin{array}{l}\text { Good to have framework to follow (4) } \\
\text { Helpful format for physicians and others to read (3) } \\
\text { Formats health information understandably (2) }\end{array}$ \\
\hline \multirow[t]{2}{*}{$\begin{array}{l}\text { Challenges in Using the SDMM } \\
(n=29)\end{array}$} & $\begin{array}{l}\text { Problem/topic placement } \\
(n=20)\end{array}$ & $\begin{array}{l}\text { Some do not seem to fit into domains ( } 7 \text { ) } \\
\text { Difficult to narrow things down to one domain (6) } \\
\text { Sorting problems/topics could be easier (6) } \\
\text { Takes time to think where certain items fit (1) }\end{array}$ \\
\hline & Change is required $(n=9)$ & $\begin{array}{l}\text { Documentation is different (5) } \\
\text { Takes time to use initially (2) } \\
\text { Why change? (2) }\end{array}$ \\
\hline
\end{tabular}

SDMM Siebens Domain Management Model (৫ Hilary C Siebens MD 2005)

components, may reduce health care organizations' PD practice variation. The nurse care manager would be the central point person, supporting individuals with PD, care partners, and providers, especially PD specialists.

The Siebens Domain Management Model offered a beneficial organizing framework across sites and among CHAPS nurse care managers. The model allowed flexibility that honored nurse care managers' judgment in prioritizing problems/topics in partnership with patients, facilitated problem/topic follow-up and documentation, and likely assisted with more succinct and effective communication with physicians. This demonstrated the model's use: (1) by nurses, adding to its use by other disciplines, (2) in the outpatient setting, adding to inpatient findings and, thus, across the care continuum, (3) in care of individuals with PD, an enduring medical condition, adding to other diagnoses already studied, and (4) as Section Headings of the self-care Notebook (Fig. 1) [23, 26, 31, 36]. Participant and nurse care manager comments about the Notebook supported the value and role for this paper-based self-management tool. It may be used alone or to augment electronic patient portals (e.g., My HealtheVet) $[45,57,58]$. Additionally, the Notebook may assist with care continuity, as in care transitions [59], within or outside health care systems [60, 61].
Efficiency in CHAPS care delivery could improve through integrating user-friendly care management software for managing patient panels/tasks and the CHAPS Assessment with its algorithms for problem identification and associated severity [8]. Given that individuals with PD exhibit a range of disease severity, appropriate panel size for CHAPS may vary. If comprehensive proactive assessments became routinely adopted early on in PD care management, follow-up care would be more efficient as problems would be anticipated and then prevented or managed more easily. Additionally, coronavirus (COVID-19) is a significant concern for individuals with $\mathrm{PD}$ as it may worsen motor-related function, urinary-related symptoms, and fatigue [62] and may impose new stressors (e.g., exacerbating social isolation, limiting exercise) [63]. Therefore, during this pandemic, CHAPS may help in care efficiency through its telehealth care management.

Given stakeholder feedback, disseminating CHAPS and its components may improve partnering across healthcare and community services, especially critical in individuals with complex medical conditions $[64,65]$. CHAPS may also decrease medical risks and hassles in managing enduring health conditions $[42,66]$ likely achieving friendlier care and greater trust $[6,67,68]$. 
Table 6 Usability survey responses from nurse care managers about the Siebens Health Care Notebook

\begin{tabular}{|c|c|c|}
\hline Themes & Attributes & Items (n) \\
\hline \multirow[t]{3}{*}{$\begin{array}{l}\text { Facilitators for coaching about the } \\
\text { Notebook } \\
(n=46)\end{array}$} & $\begin{array}{l}\text { Organized } \\
(n=18)\end{array}$ & $\begin{array}{l}\text { Organized structure (8) } \\
\text { Places for types of information (5) } \\
\text { Concise (2) } \\
\text { Separated into sections (2) } \\
\text { Kept nurse care manager organized in patient care (1) }\end{array}$ \\
\hline & $\begin{array}{l}\text { User-friendly } \\
(n=15)\end{array}$ & $\begin{array}{l}\text { Practical (6) } \\
\text { Easy to use (4) } \\
\text { Does what it is designed to do (2) } \\
\text { Handy for keeping records (2) } \\
\text { Good place to hold information (1) }\end{array}$ \\
\hline & $\begin{array}{l}\text { Person/Patient-Centered } \\
(n=13)\end{array}$ & $\begin{array}{l}\text { Comprehensive (2) } \\
\text { Empowering (2) } \\
\text { Veteran-specific materials added (2) } \\
\text { Great solution for veterans with complex health issues (2) } \\
\text { Main communication device among providers (1) } \\
\text { Tool for coordinating care with community providers (1) } \\
\text { Has a specific sheet for writing questions for providers (1) } \\
\text { Provides important information for making choices (1) } \\
\text { Veterans can use as much or as little as they like (1) }\end{array}$ \\
\hline \multirow[t]{2}{*}{$\begin{array}{l}\text { Challenges to coaching about the } \\
\text { Notebook } \\
(n=28)\end{array}$} & $\begin{array}{l}\text { Incorporating individuals' abilities/ } \\
\text { preferences } \\
(n=14)\end{array}$ & $\begin{array}{l}\text { Everyone is different (3) } \\
\text { Some veterans have their own ways of organizing } \\
\text { information ( } 3 \text { ) } \\
\text { Individualized teaching depending on veteran's situation ( } 2 \text { ) } \\
\text { Hard to carry for some veterans with Parkinson disease (2) } \\
\text { More than } 1-2 \text { pages is difficult (1) } \\
\text { Some veterans with too much on their minds (1) } \\
\text { Some veterans love it, some do not (1) } \\
\text { Better to teach about Notebook in person than over the } \\
\text { phone (1) }\end{array}$ \\
\hline & $\begin{array}{l}\text { Notebook layout } \\
(n=14)\end{array}$ & $\begin{array}{l}\text { Information could be consolidated (2) } \\
\text { Too many sections (2) } \\
\text { More specific to Parkinson (2) } \\
\text { Bulky (2) } \\
\text { Too much white (1) } \\
\text { The location of My Action Plan (1) } \\
\text { Pages not numbered so is hard to find contents (1) } \\
\text { Patient's printed medication list may be outdated (1) } \\
\text { Not very useful (1) } \\
\text { Old-fashioned (1) }\end{array}$ \\
\hline
\end{tabular}

Notebook - Siebens Health Care Notebook

\section{Conclusions}

Overall, stakeholder perceptions of the proactive nurseled CHAPS intervention indicated its value in the care of individuals with PD. Responses about the CHAPS Assessment, Siebens Domain Management Model, and Notebook self-care tool signified their usefulness. Stakeholders' constructive suggestions indicated their engagement in CHAPS. These findings support CHAPS dissemination and contribute to research in care management.

\section{Supplementary Information}

The online version contains supplementary material available at https://doi. org/10.1186/s12883-020-02011-9.

Additional file 1. Example of CHAPS Assessment for gastro-intestinalrelated problems/topics. LEGEND: Items in caps are CHAPS problem/ topics with associated intervention protocols: assess further, provide information, problem solve collaboratively, clinical referral, and community and social service referral. Less severe symptoms elicited only nurse care manager to review the problem further with the patient, referring to review intervention protocol as needed. More severe symptoms also triggered referrals to health providers (e.g., Parkinson's disease specialist) [23] CHAPS - Care Coordination for Health Promotion and Activities in Parkinson's Disease; MD - medical doctor or other health provider.

Additional file 2. Self-care Tool: My Action Plan. LEGEND: Text $\left(^{*}\right)$ were cues for topics to be discussed in each section. The text could be left unchanged, deleted, or expanded by the nurse care manager. This Plan was placed in each participant's personalized Notebook and updated as appropriate [23].

\section{Abbreviations}

CHAPS: Care Coordination for Health Promotion and Activities in Parkinson's Disease; PD: Parkinson disease; Notebook: Siebens Health Care Notebook; SD: Standard deviation; CTM-15: Care Transition Measure; SAS: Statistical analysis software

\section{Acknowledgements}

We wish to thank all CHAPS nurse care managers, Parkinson disease specialists, and CHAPS participants (veterans) that provided responses to the surveys. We also wish to thank CARF International for providing the Siebens Health Care Notebooks. 


\section{Authors' contributions}

The authors' responsibilities were as follows: KIC and BSM conceived and designed the research. LKE and MGM collected the data. FB conducted and supervised the analyses. HCS, BSM, DAG, DKM, EMC, and BGV provided advice on study design and analysis and interpretation of the results. KIC and HCS were responsible for drafting the manuscript. LKE was the overall coordinator of the CHAPS project, implemented in collaboration with the principal investigators in the five participating Veterans Affairs Healthcare Systems. All authors read and approved the final manuscript.

\section{Funding}

This work was funded by the Veteran Affairs Health Services Research and Development - Nursing Research Initiative (VA HSR\&D-NRI) 11-126. Supplemental funding was received from the Center for the Study of Healthcare Innovation, Implementation and Policy (CSHIIP) VA Los Angeles, CA as a LIP funding supplement to VA HSR\&D-NRI 11-126. Funders were not involved in designing the study; collecting, analyzing, or interpreting the data; or in writing or submitting the manuscript for publication. Where authors are identified as personnel of the Veterans Affairs, the authors alone are responsible for the views expressed in this article and they do not necessarily represent the decisions, policy, or views of the Veterans Affairs.

\section{Availability of data and materials}

The datasets generated and/or analyzed during the current study are not publicly available as, by the time we deidentify data to the degree acceptable, too many key variables are taken out given that veterans can be re-identified with enough social and/or personal demographic and area information. Additionally, the small pool of intervention nurse care managers and Parkinson's disease specialists would potentially allow tracing qualitative survey data back to them.

\section{Ethics approval and consent to participate}

Institutional Review Boards (IRB) of the five participating Veterans Affairs Healthcare Systems (Greater Los Angeles, Long Beach, Loma Linda, and San Diego, California; and Las Vegas, Nevada) gave permission for the study on November 9, 2011. The Clinical Trial Registration, NCT01532986, was listed on January 13, 2012. The IRBs waived the requirement for documentation of written consent and allowed verbal consent for the participants (veterans).

\section{Consent for publication}

Not applicable.

\section{Competing interests}

The authors declare that they have no competing interests except Hilary $C$ Siebens, MD who uses the 4-domain clinical organizing framework she designed, Siebens Domain Management Model ${ }^{T M}$, in consulting work with health care organizations and others. Also, she is the author of the Siebens Health Care Notebook, a self-care tool.

\section{Author details}

'Veterans Affairs Parkinson's Disease Research, Education and Clinical Center, Los Angeles, CA, USA. UCLA David Geffen School of Medicine, Los Angeles, CA, USA. ${ }^{3}$ Novato, CA, USA. ${ }^{4}$ Siebens Patient Care Communications LLC, Seal Beach, CA, USA. ${ }^{5}$ Kaiser Permanente Research, Pasadena, CA, USA. ' UCLA School of Nursing, Los Angeles, CA, USA. Veterans Affairs Geriatric Research, Education and Clinical Center and Center for the Study of Healthcare Innovation, Implementation and Policy, Los Angeles, CA, USA. ${ }^{8}$ Icahn School of Medicine at Mount Sinai, New York, NY, USA.

Received: 15 June 2020 Accepted: 23 November 2020

Published online: 02 December 2020

\section{References}

1. Gray BH, Sarnak DO, Tanke M. ParkinsonNet: an innovative Dutch approach to patient-centered care for a degenerative disease. Commonwealth Fund; 2016. p. 1-11.

2. Bloem BR, Rompen $L$, de Vries NM, Klink A, Munneke $M$, Jeurissen $P$. ParkinsonNet: a low-cost health care innovation with a systems approach from the Netherlands. Health Aff. 2017;36:1987-96.

3. Dorsey ER, Shere T, Okun MS, Bloem BR. The emerging evidence of the Parkinson pandemic. J Park Dis. 2018;8:S3-8.
4. Brundin P, Bloem BR. The time they are a-changin': Parkinson disease 20 years from now. J Park Dis. 2018;8:S1-2.

5. World Health Organization. Age-friendly Primary Health Care Centres Toolkit. Geneva: Who Press; 2008. p. 1-117.

6. Fulmer T, Mate KS, Berman A. The age-friendly health system imperative. JAGS. 2018;66:22-4

7. van der Marck MA, Bloem BR, Borm GF, Overeem S, Munneke M, Guttman M. Effectiveness of multidisciplinary care for Parkinson disease: a randomized, controlled trial. Mov Disorders. 2013;26:605-11.

8. Connor K, Cheng E, Siebens HC, et al. Study protocol of "CHAPS": a randomized controlled trial protocol of care coordination for health promotion and activities in Parkinson disease to improve the quality of care for individuals with Parkinson disease. BMC Neurol. 2015;15:258.

9. Connor Kl, Cheng EM, Barry F, Siebens HC, Lee ML, Ganz DA, Mittman BS, Connor MK, Edwards LK. McGowan, Vickrey BG. Randomized trial of care management to improve Parkinson disease care quality. Neurology. 2019; 92(16):e1831-42.

10. Dearing JW. Applying diffusion of innovation theory to intervention development. Res Soc Work Pract. 2009;19:503-18.

11. Frampton SB, Gilpin L, Charmel PA. Putting patients first - designing and practicing patient-centered care. San Francisco: Jossey-Bass; 2003.

12. Starfield B. Is patient-centered care the same as person-focused care? Perm J. 2011;15:63-9.

13. American Geriatrics Society Expert Panel on Person-Centered Care. Personcentered care: a definition and essential elements. J Am Geriatr Soc. 2016; 64:15-8.

14. van der Eijk M, Faber JM, Al Shamma S, Munneke M, Bloem BR. Moving towards patient-centered healthcare for patients with Parkinson disease. Parkinsonism Relat Disord. 2011;17:360-4.

15. van der Eijk M, Faber MJ, Ummels I, Aarts JWM, Munneke M, Bloem BR. Patient-centeredness in PD care: development and validation of a patient experience questionnaire. Parkinsonism Relat Disord. 2012;18:1011-6.

16. Vlaanderen FP, Rompen L, Munneke M, Stoffer M, Bloem BR, Faber MJ. The voice of the Parkinson customer. J Park Dis. 2019;9:197-201.

17. Higgins T, Larson E, Schnall R. Unraveling the meaning of patient engagement: a concept analysis. Patient Educ Couns. 2017;100:30-6.

18. Perreira TA, Perrier L, Prokopy M. Hospital physician engagement: a scoping review. Med Care. 2018;56:969-75.

19. Dempsey C, Assi MJ. The impact of nurse engagement on quality, safety, and the experience of care: what nurse leaders should know. Nurs Adm Q. 2018;42:278-83.

20. Miake-Lye IM, Chuang E, Rodriguez HP, Kominski GF, Yano EM, Shortell SM. Random or predictable? Adoption patterns of chronic care management practices in physician organizations. Implementation Sci. 2017;12:106.

21. Wagner EH, Austin BT, Von Korff M. Organizing care for patients with chronic illness. Milbank Q. 1996;74(4):511-44.

22. Cheng EM, Tonn S, Swain-Eng R, Factor SA, Weiner WJ, Bever CT. Quality improvement in neurology: AAN Parkinson disease quality measures: report of the quality measurement and reporting Subcommittee of the American Academy of neurology. Neurology. 2010;75(22):2021-7.

23. Connor Kl, Siebens HC, Mittman BS, Ganz DA, Barry F, Ernst EJ, Edwards LK, McGowan MG, McNeese-Smith DK, Cheng EM, Vickrey BG. Quality and extent of implementation of a nurse-led care management intervention: care coordination for health promotion and activities in Parkinson's disease (CHAPS). BMC Health Serv Res. 2020;20:732.

24. Siebens H. The Siebens Health Care Notebook 2008; 2018.

25. Siebens H. Proposing a practical clinical model. Top Stroke Rehabil. 2011;18: 60-5.

26. Siebens $\mathrm{H}$, Sharkey $\mathrm{P}$, Aronow HU, Deutscher D, Roberts $\mathrm{P}$, Munin MC, Radnay C, Horn SD. Variation in rehabilitation treatment patterns for hip fracture treated with arthroplasty. PM\&R. 2016;8:191-207.

27. Kozier B, Erb G, Blais K, Wilkinson JM. Fundamentals of nursing - concepts, process, and practice. Menlo Park: Addison-Wesley; 1998.

28. Siebens $\mathrm{H}$. The domain management model: organizing care for stroke survivors and other persons with chronic diseases. Top Stroke Rehabil. 2002; 9:1-25.

29. Engel G. The need for a new medical model. Science. 1977;196:129-36.

30. Stineman MG, Streim T. The biopsycho-ecological model - a foundational theory for medicine. PM\&R. 2010;2:1035-45.

31. Kushner DS, Peters K, Johnson-Greene D. Evaluating use of the Siebens domain management model during inpatient rehabilitation to increase 
functional independence and discharge rate to home in stroke patients. PMR. 2015a;7:354-64.

32. Kushner DS, Peters KM, Johnson-Greene D. Evaluating Siebens domain management model for inpatient rehabilitation to increase functional independence and discharge rate to home in geriatric patients. Arch Phys Med Rehabil. 2015b;96:1310-8.

33. Kushner DS, Peters K, Johnson-Greene D. Evaluating the Siebens model in geriatric-stroke inpatient rehabilitation to reduce institutionalization \& acute care readmissions. J Stroke Cerebrovasc Dis. 2016;25:317-26.

34. Clark GS, Kortebein P, Siebens HC. Aging and rehabilitation. In: DeLisa J, Gans B, editors. DeLisa's physical medicine and rehabilitation: principles and practice. 5th ed. Philadelphia: J.B. Lippincott Company; 2010. p. 1545-85.

35. BATES Caring for Older Adults: The Siebens Domain Management Model in Hogan, Quigley B, Palm ML, Bickley B. Bates Nursing Guide to Physical Examination and History Taking. Philadelphia: Lippincott, Williams, and Wilkins; 2012. p. 878.

36. Kim W, Charchian B, Chang E, Liang L, Dumas A, Perez M, Siebens H, Kim HS. Strengthening information capture in rehabilitation discharge summaries: an application of the Siebens domain management model. PM\&R. 2013;5:182-8.

37. Connor Kl, Siebens H, Chodosh J. Chapter 14 Person-centered approaches to caregiving. In: Gaugler J, Kane R, editors. Family Caregiving in the New Normal. Cambridge: Academic Press; 2015. p. 251-68.

38. Siebens $\mathrm{HC}$, Aronow H, Edwards DE, Ghasemi Z. A randomized controlled trial of exercise to improve outcomes of acute hospitalization in older adults. J Am Geriatr Soc. 2000;48:1545-52.

39. Mendoza RH, Pittenger D, Weinstein CS. Unit management of depression of patients with multiple sclerosis using cognitive remediation strategies: a preliminary study. Neurorehabil Neural Repair. 2001;15:9-14.

40. Jones C, Skirrow P, Griffiths R, et al. Rehabilitation after critical illness: a randomized, controlled trial. Crit Care Med. 2003;31:2456-61.

41. Siebens H, Weston H, Parry D, Cooke E, Knight R, Rosato E. The patient care notebook: quality improvement on a rehabilitation unit. J Qual Improv. 2001;27:555-67.

42. Siebens H, Randall P. The patient care notebook: from pilot phase to successful hospital-wide dissemination. J Qual Patient Safety. 2005;31:398-405.

43. Coleman EA, Smith JD, Frank JC, Min SJ, Parry C, Kramer AM. Preparing patients and caregivers to participate in care delivered across settings: The Care Transitions Intervention. J Am Geriatr Soc. 2004;52:1817-25.

44. Coleman EA, Parry C, Chalmers S, Min SJ. The care transitions intervention results of a randomized controlled trial. Arch Intern Med. 2006;166:1822-8.

45. Bergeson SC, Dean JD. A systems approach to patient-centered care. JAMA. 2006;296:2848-51.

46. Moyo P, Walters D, Siebens HC, Myers J, Baynes R, Cook-Wiens G, Jo M, Asher A. Perceptions of a health care notebook from female breast cancer survivors with cognitive impairment. J Cancer Educ. 2020, p 1-7.

47. Kleiner-Fisman G, Stern MB, Fisman DN. Health-related quality of life in Parkinson disease: correlation between Health Utilities Index III and Unified Parkinson's Disease Rating Scale (UPDRS) in U.S. male veterans. Health Qual Life Outcomes. 2010;8:91.

48. Pohar SL, Jones AC. The burden of Parkinson disease (PD) and concomitant comorbidities. Arch Gerontol Geriatr. 2009;49:317-21.

49. Care Transitions Measure (CTM-15) https://caretransitions.org/wp-content/ uploads/2015/08/CTM-15.pdf Accessed 13 Feb 2019.

50. Chodosh J, Connor K, Batra R, Osterweil D. A Geriatric Assessment Center for Patients with High Geriatric Need: Patient and Provider Quality Ratings. [Unpublished Abstract] Presidential Poster Session; American Geriatric Society Annual Scientific Meeting, May 18th, 2017 San Antonio, Texas.

51. Underwood C. In: Sirageldin I, editor. Chapter 15 Belief and attitude change in the context of human development. in Sustainable Human Development in the Twenty-first Century, vol. II; 2009. p. 1-22.

52. Ergonomics of human-system interaction - Part ii: Usability: Definitions and concepts. International Standard ISO 9241-11. Second edition, 2018-03. International Organization for Standardization, Geneva. pp. 1-28.

53. Web Accessibility Initiative (WAI) Site Usability Testing Questions 2003 at http:// www.w3.org/WAl/EO/Drafts/UCD/questions.html. Accessed 16 June 2019.

54. Ryan GW, Bernard HR. Techniques to identify themes. Field Methods. 2003; 15:85-109.

55. Connor K, McNeese-Smith D, van Servellen G, Change B, Lee M, Cheng E, Hajar A, Vickrey BG. Insight into dementia care management using socialbehavioral theory and mixed methods. Nurs Res. 2009;58:348-58.
56. Chodosh J, Pearson ML, Connor KI, Vassar SD, Kaisey M, Lee ML, Vickrey BF. A dementia care management intervention: which components improve quality? Am J Manag Care. 2012;18:85-94.

57. Jabr F. Why the brain prefers paper. Sci Am. 2013;309:49-53.

58. Klucken J, Krüger R, Schmidt P, Bloem BR. Management of Parkinson disease 20 years from now: towards digital health pathways. J Park Dis. 2018;8:585-94.

59. Scotten M, Manos EL, Malicoat A, Paolo AM. Minding the gap: interprofessional communication during inpatient and post discharge chasm care. Patient Educ Couns. 2015;98:895-900.

60. Jones CD, Cumbler E, Honigman B, Burke RE, Boxer RS, Levy C, Coleman EA, Wald HL. Hospital to post-acute care facility transfers: identifying targets for information exchange quality improvement. JAMDA. 2017;18:70-3.

61. Cogan A, Cervelli L, Dillahunt-Aspillaga C, Rossiter AG. Treating military service members and veterans in the private sector: information and resources for clinicians. Information/Education Page. Arch Phys Med Rehabil. 2018:99:2659-61.

62. Cilia R, Bonvegna S, Straccia G, Andreasi NG, Elia AE, Romito LM, Devigili G, Cereda E, Eleopra R. Effects of COVID-19 on Parkinson's disease clinical features: a community-based case-control study. Mov Disorders. 2020;35: 1287-92.

63. Helmich RC, Bloem BR. The impact of the COVID-19 pandemic on Parkinson's disease: hidden sorrows and emerging opportunities. J Park Dis. 2020;10:351-4.

64. Tinetti ME, Fried TR, Boyd CM. Designing health care for the most common chronic condition - multimorbidity. JAMA. 2012;307:2493-4.

65. Szanton SL, Xue QL, Leff B, Guralnik J, Wolff JL, Tanner EK, Boyd C, Thorpe RJ, Bishai D, Gitlin LN. Effect of a biobehavioral environmental approach on disability among low-income older adults: a randomized clinical trial. JAMA Intern Med. 2019;179:204-11.

66. Sarid O, Slomin-Neva V, Sergienko R, Pereg A, Chernin E, Singer T, Greenberg D, Schwartz D, Vardi H, Friger M, Odes S. Daily hassles score associates with the somatic and psychological health of patients with Crohn's disease. J Clin Psychol. 2018;74:969-88.

67. Dracup K, Bryan-Brown CW. On notebooks and trust. Am J Crit Care. 2002; 11:96-9.

68. Henneman B. Letters to the editor. Am J Crit Care. 2002;11:195-6.

\section{Publisher's Note}

Springer Nature remains neutral with regard to jurisdictional claims in published maps and institutional affiliations.

Ready to submit your research? Choose BMC and benefit from:

- fast, convenient online submission

- thorough peer review by experienced researchers in your field

- rapid publication on acceptance

- support for research data, including large and complex data types

- gold Open Access which fosters wider collaboration and increased citations

- maximum visibility for your research: over $100 \mathrm{M}$ website views per year

At BMC, research is always in progress.

Learn more biomedcentral.com/submissions 